\section{Porcine red blood cells express a polyagglutinable red blood cell phenotype}

The shortage of human blood and organs has led to increased interest in animal substitutes. In both transplantation and transfusion, the greatest roadblock to the use of animal tissues is the expression of xenoantigens. A major xenoantigen in pigs is linear B (Gal $\alpha 1-3 \mathrm{Gal} \beta 1$ 4GlcNAc-R), a cross-reactive, B-like antigen expressed on red blood cells (RBCs) and other tissues that is recognized by naturally occurring antibodies present in human serum. ${ }^{1,2}$

Recently, Rouhani and colleagues ${ }^{2}$ reported their experience with porcine RBCs (pRBCs) from genetically engineered pigs that lack linear B ( $\alpha$ l,3-galactosyltransferase knockouts $[\alpha \mathrm{Gal}-]) .^{2}$ Relative to wild-type controls, pRBCs from $\alpha \mathrm{Gal}-$ animals showed a marked decrease in hemolysis and immunoglobulin $\mathrm{G}$ and immunoglobulin $M$ binding after incubation in human serum. Although decreased, antibody binding to $\alpha$ Gal- pRBCs still occurred, suggesting the presence of other xenoantigens. This was confirmed by in vivo studies in baboons, which showed rapid clearance ( $<5 \mathrm{~min})$, with evidence of hemolysis, for $\alpha \mathrm{Gal}-$ and wild-type pRBCs. It was hypothesized that pRBCs were removed by hepatic macrophages, possibly via an endogenous lectin on Kupffer cells.

We would like to share our serologic results using lectins of defined specificity, which showed that pRBCs express a polyagglutinable phenotype that is independent of linear B expression. Several years ago, one of us (J.L.S.) routinely typed pigs for the transplant surgery research program. Washed pRBCs were forward typed as group A or "O" with commercial murine monoclonal antibodies (MoAbs) by standard-tube agglutination (Table 1). No animal typed as group B. The presence of linear B was confirmed in a small cohort of animals with Griffonia simplicifolia (GS1), which recognizes terminal $\alpha$ galactose. ${ }^{3}$

As shown in Table 1, regardless of $\mathrm{ABO}$ type, 99 percent of all animals tested were T-antigen-positive (Arachis hypogaea, PNA). Only three animals were PNAnegative, including two littermates, indicating that PNA+ was an autosomal dominant phenotype. In addition to PNA, 90 to 100 percent of animals tested were also positive with Glycine soya (SBA), Salvia sclarea (SSA), and Salvia horminum (SHA). Most animals were also positive with the anti-A lectins Dolichos biflorus (DBA) and Phaseolus lunatus (LBA). Titration and adsorption studies suggested

\begin{tabular}{|c|c|c|c|c|c|c|}
\hline \multirow[b]{4}{*}{ Reagent } & \multirow{2}{*}{\multicolumn{2}{|c|}{ Reagent specificity }} & \multicolumn{4}{|c|}{ Serologic typing of $p R B C^{*}$} \\
\hline & & & \multirow{3}{*}{$\begin{array}{c}\text { Total } \\
\text { number of } \\
\text { pigs tested }\end{array}$} & \multirow{3}{*}{$\begin{array}{c}\text { Number }(\%) \\
\text { of pigs } \\
\text { positive }\end{array}$} & \multirow{2}{*}{\multicolumn{2}{|c|}{ Results by pig ABO type }} \\
\hline & \multirow{2}{*}{$\begin{array}{c}\text { Carbohydrate } \\
\text { epitope }\end{array}$} & \multirow{2}{*}{$\begin{array}{l}\text { Blood } \\
\text { group }\end{array}$} & & & & \\
\hline & & & & & Group O† & Group A† \\
\hline Anti-A MoAb† & GalNAc $\alpha 1-3(F u c \alpha 1-2) G a l$ & A & 401 & 130 & $271 \dagger$ & 130 \\
\hline Anti-A human $\ddagger$ & GalNAc $\alpha 1-3($ Fuc $\alpha 1-2)$ Gal & A & 20 & 20 & 10 & 10 \\
\hline Anti-B MoAbt & Gal $1-3$ (Fuc $\alpha 1-2) \mathrm{Gal}$ & B & 401 & 0 & 0 & 0 \\
\hline G. simplicifolia (GS-1) & $\alpha \mathrm{Gal}$ & B, linear B & 29 & 29 & NA§ & NA \\
\hline Ulex europeaus (UEA-1) & $\alpha$ Fuc & $\mathrm{H}(\mathrm{O})$ & 146 & 0 & 0 & 0 \\
\hline D. biflorus (DBA)\| & $\alpha$ GalNAc & $A_{1}$ & 411 & $391(95)$ & $166(93)$ & $68(94)$ \\
\hline Strong positive (3-4+) & & & & $375(91)$ & $156(88)$ & $67(93)$ \\
\hline Weak positive (1-2+) & & & & $16(4)$ & $10(5)$ & $1(1)$ \\
\hline Negative $( \pm-0)$ & & & & $20(5)$ & $12(7)$ & $4(6)$ \\
\hline Phaseolus lunatus (LBA) & $\alpha$ GalNAc & A & 29 & $24(83)$ & $\mathrm{NA}$ & NA \\
\hline A. hypogaea (PNA)\| & Galß1-3GalNAc & $\mathrm{T}$ & 264 & 261 (99) & $175(99)$ & $71(98)$ \\
\hline Strong positive & & & & $256(97)$ & $173(97)$ & $68(94)$ \\
\hline Weak positive & & & & $5(2)$ & $3(2)$ & $3(4)$ \\
\hline Negative & & & & $3(1)$ & $2(1)$ & $1(1)$ \\
\hline G. soya (SBA) & GalNAc & $\mathrm{T}, \mathrm{Tn}, \mathrm{CAD}$ & 29 & $29(100)$ & NA & NA \\
\hline S. sclarea (SSA) & GalNAc & Tn & 29 & $29(100)$ & NA & NA \\
\hline S. horminum (SHA)ף & GalNAc & Tn, CAD & 29 & $24(83)$ & NA & NA \\
\hline Bauhinia purpurea (BPA) & Gal/GalNAc & $\mathrm{T}$, lactose & 29 & $26(90)$ & NA & NA \\
\hline $\begin{array}{l}\text { Data are reported as nur } \\
\text { † Porcine RBCs were forwa } \\
\text { did not agglutinate with a } \\
\text { by anti-H lectin, UEA-1. } \\
\text { † Human anti-A was exten } \\
\text { § NA = not available. } \\
\text { II Reactions of pRBCs wer } \\
\text { with the lectins DBA and } \\
\text { q Variable agglutination str }\end{array}$ & $\begin{array}{l}\text { typed with anti-A and anti-B } \\
A \text { and anti-B MoAbs were in } \\
\text { ass adsorbed using group } \\
\text { as. } \\
\text { th between animals (range, }\end{array}$ & $\begin{array}{l}\text { ine MoAbs ac } \\
\text { oreted to be } g \\
\text { Cs to remove } \\
\text {, weak positiv } \\
\text { 3+). }\end{array}$ & $\begin{array}{l}\text { ling to manufa } \\
O(n=271 \text { a } \\
\text { ti- } \alpha \text { Gal. } \\
-2+) \text {, and neg }\end{array}$ & $\begin{array}{l}\text { rer's instruction } \\
\text { nals). Note that } \\
e( \pm-0) \text { based o }\end{array}$ & $\begin{array}{l}\text { or human RB } \\
\text { pRBCs were }\end{array}$ & $\begin{array}{l}\text { RBCs that } \\
\text { gglutinated } \\
\text { gglutination }\end{array}$ \\
\hline
\end{tabular}




\begin{tabular}{|lcccccccc|}
\hline \multicolumn{7}{|c|}{ TABLE 2. Comparison of pRBCs and polyagglutinable human } \\
RBC phenotypes
\end{tabular}

\author{
Laura Cooling, MD, MS \\ Department of Pathology \\ University of Michigan Hospitals \\ Ann Arbor, MI 48109-0054 \\ e-mail:lcooling@med.umich.edu
}

\title{
REFERENCES
}

1. Strokan V, Rydberg L, Hallberg EC, Molne J, Breimer ME. Characterisation of human natural anti-sheep xenoantibodies. Xenotransplantation 1998;5:111-21.

that DBA recognized a unique, cross-reactive A-like antigen on pRBCs. The latter may represent the $\mathrm{A}^{\mathrm{p}}$ antigen defined in older literature. There was no correlation between PNA and DBA positivity ( $\mathrm{p}=0.24$, chi-square).

These studies support the contention of Rouhani and coworkers $^{2}$ that pRBCs may express additional carbohydrate epitopes, capable of binding naturally occurring antibodies and/or endogenous lectins, to affect pRBC hemolysis and removal. A similar conclusion was reported by Gautreau and associates ${ }^{4}$ who observed strong hemagglutination of pRBCs with human serum depleted of antiA, anti-B, and linear B agglutinins. ${ }^{4}$ Finally, multiple glycolipid antigens in pigs and sheep were recently identified as potential novel xenoantigens, as evidenced by their reactivity with $A B$ human serum that had been depleted of Forssman and $\alpha \mathrm{Gal}$ antibodies by immune adsorption. $^{1}$

Our results show that $\mathrm{pRBC}$ share features with many polyagglutinable RBC phenotypes (Table 2). A known senescent antigen on human RBCs, T-antigen is clinically associated with hemolysis and shortened in vivo survival. ${ }^{3}$ Shortened RBC survival and hemolysis are also observed in patients with the Tn syndrome. ${ }^{3}$ Interestingly, the Tk antigen has been implicated in the short survival of platelets stored at $4^{\circ} \mathrm{C}$. Cold storage is associated with the exposure and clustering of Tk antigen present on glycoprotein-Ib $\alpha$, which is subsequently recognized by $\alpha_{M} \beta_{2}$ integrin receptor (complement receptor 3) on hepatic macrophages. ${ }^{5}$

In summary, these results emphasize the problems facing xenotransplantation. Genetically engineered animals, which lack linear B antigen and/or Forssman antigen expression, may still be quite antigenic owing to species-specific differences in the regulation and expression of other carbohydrate antigens. More research into the differentiation and regulation of cell surface glycosylation in humans and animals is needed.

Jane L. Swanson, MS Emerita Research Fellow Department of Laboratory Medicine and Pathology University of Minnesota Hospital and Clinic Minneapolis, MN 55455
2. Rouhani FJ, Dor FJ, Cooper DK. Investigation of red blood cells from $\alpha 1,3$-galactosyltransferase-knockout pigs for human blood transfusion. Transfusion 2004;44: 1004-12.

3. Issitt PD, Anstee DJ. Applied blood group serology, 4th ed. Durham (NC): Montgomery Scientific Publications; 1998.

4. Gautreau C, Cardoso J, Jeyaraj P, Houssin D, Weill B. Relationship between human natural anti-A, anti-B alloantibodies and anti-pig xenoantibodies. Transplant Proc 1993;25:389-91.

5. Hoffmeister KM, Josefsson EC, Isaac NA, et al. Glycosylation restores survival of chilled blood platelets. Science 2003; 301:1531-4.

The above letter was sent to Rouhani et al.: Drs Dor, Rouhani, and Cooper offered the following reply.

We read with interest the letter by Swanson and Cooling, ${ }^{1}$ written in response to our recent article, ${ }^{2}$ in which they provide evidence that porcine red blood cells ( $\mathrm{pRBCs}$ ) express a polyagglutinable phenotype that is independent of $\alpha 1$,3-galactosyltransferase ( $\alpha \mathrm{Gal}$; linear B) expression. We fully agree with them that xenoantigenicity is still present in $\alpha \mathrm{Gal}$ gene-knockout pigs. As they provide evidence, other xenoantigens are present on pRBCs; ${ }^{3}$ one such example has been demonstrated by Zhu and Hurst ${ }^{4}$ to be $N$-glycolylneuraminic acid. Furthermore, knocking out the $\alpha \mathrm{Gal}$ gene may alter the glycosylation pattern on cell surfaces, as reported by Shinkel and coworkers, ${ }^{5}$ resulting in exposure of neoantigens, which could lead to destruction of these pig cells by antibodies or other constituents of the host immune response. One potential partial solution to this problem would be to replace the $\alpha \mathrm{Gal}$ epitopes with another oligosaccharide (through transgenic expression of a human gene) that would not be bound by human antibodies, for example, that for the $\mathrm{H}(\mathrm{O})$ blood group oligosaccharide. ${ }^{6,7}$ 
Frank J.M.F. Dor, MD

Department of Surgery

Erasmus MC Rotterdam

PO Box 2040

3000 CA Rotterdam, the Netherlands

Foad Rouhani, MB, BCh

Christ's College

Cambridge CB2 3BU, UK

David K.C. Cooper, MD, PhD, FRCS

Thomas E. Starzl Transplantation Institute

University of Pittsburgh Medical Center

Biomedical Sciences Tower East, Room E1550A

200 Lothrop Street

Pittsburgh, PA 15261

e-mail: cooperdk@upmc.edu

\section{REFERENCES}

1. Swanson JL, Cooling L. Porcine red blood cells express a polyagglutinable red blood cell phenotype [letter]. Transfusion 2005;45:1035-6.

2. Rouhani FJ, Dor FJ, Cooper DK. Investigation of red blood cells from $\alpha 1,3$-galactosyltransferase-knockout pigs for human blood transfusion. Transfusion 2003;44:1004-12.

3. Cooper DK. Xenoantigens and xenoantibodies. Xenotransplantation 1998;5:6-17.

4. Zhu A, Hurst R. Anti-N-glycolylneuraminic acid antibodies identified in healthy human serum. Xenotransplantation 2002;9:376-81.

5. Shinkel TA, Chen CG, Salvaris E, et al. Changes in cell surface glycosylation in $\alpha 1,3$-galactosyltransferase-knockout and $\alpha 1,2$-fucosyltransferase transgenic mice. Transplantation 1997;64:197-204.

6. Sandrin MS, Fodor WL, Mouhtouris E, et al. Enzymatic remodelling of the carbohydrate surface of a xenogeneic cell substantially reduces human antibody binding and complement mediated cytolysis. Nat Med 1995;1:1261-7.

7. Ramsoondar JJ, Machaty Z, Costa C, et al. Production of $\alpha 1,3$-galactosyltransferase-knockout cloned pigs expressing human $\alpha 1$,2-fucosyltransferase. Biol Reprod 2003;69:437-45.

\section{Travel-related hepatitis A detected by hepatitis A virus RNA donor screening}

We read with interest the report by Gowland and coworkers $^{1}$ describing molecular and serologic tracing of transfusion-transmitted hepatitis A virus (HAV) between a blood donor and recipient. We describe the application of reverse transcription-polymerase chain reaction (RTPCR) and phylogenetic analysis to tracing acute hepatitis A infections in two blood donors to a common source of HAV infection during their vacations in Egypt.
Within a 3-week period, two blood donations from different regions of Germany (Donor A, July 22, 2004; and Donor B, August 12, 2004) tested positive by HAV PCR during routine processing at the Red Cross Blood Transfusion Service West. Both donors were asymptomatic and neither had been vaccinated against hepatitis A. Both had recently returned from holiday trips to Hurghada, Egypt, where they stayed in different, but neighboring, Red Sea beach hotels. They were not deferred as blood donors, because Hurghada is not a known risk area.

Routinely, all blood donated at the Red Cross Blood Transfusion Service West is tested by PCR for HCV, human immunodeficiency virus-1 (mandatory by German Guidelines), hepatitis B virus, parvovirus B19 DNA, and HAV RNA in accordance with requirements of the plasma fractionation industry. ${ }^{2}$ PCR screening of plasma is conducted using 96-sample minipools at the Laboratory of the Red Cross Blood Transfusion Service Baden-WuerttembergHessen by real-time PCR. PCR-positive minipools are traced back by chessboard-pooling and confirmed by single-donation PCR.

Additional testing for these two donors included quantitative PCR performed by one-tube RT-PCR (RealArt HAV LC RT-PCR kits, artus GmbH, Hamburg, Germany). Full-length RNA was reverse-transcribed and subsequently amplified and sequenced (DNA Cloning Service, Hamburg, Germany). Sequence data analysis was performed by CLUSTAL W algorithm. Quantification of HAV with the donors' fresh frozen plasma revealed titers of $2.5 \mathrm{EE} 2 \mathrm{IU}$ per $\mathrm{mL}$ (Donor A) and 5.3 EE3 IU per $\mathrm{mL}$ (Donor B). The closest sequence match to GenBank was HAV strain 2F84 (97\%) from a sporadic case in France in $1984 .^{3}$ Sequence analysis of both strains isolated from the plasma units revealed 100 percent homology, confirming a common source of their infections. Sequence alignment to known strains of HAV matched genotype 1B for both donations (Fig. 1). Typically, genotype 1A predominates in Germany.

The donors were informed about their test results, asked for follow-up blood samples, and interviewed by telephone to investigate the possible sources for their HAV infections. No follow-up sample was available from Donor A. His family doctor reported that he was hospitalized on August 5, 2004, because of jaundice, abdominal pain, fatigue, and loss of appetite. Hepatitis A was diagnosed and confirmed by the presence of anti-HAV immunoglobulin M (IgM) and immunoglobulin G (IgG). His apartase aminotransferase level was $11,120 \mathrm{U}$ per $\mathrm{L}$ and his alanine aminotransferase level was 5,664 U per mL. He recovered in 2 weeks. A follow-up sample from Donor B from August 19, 2004, was positive for both anti-HAV IgM and IgG and HAV PCR. He was asymptomatic, but 9 days later, he developed fever, pain in the upper abdomen, arthralgies, and one episode of dark urine. This illness lasted 2 days. The specific source of their infections has 


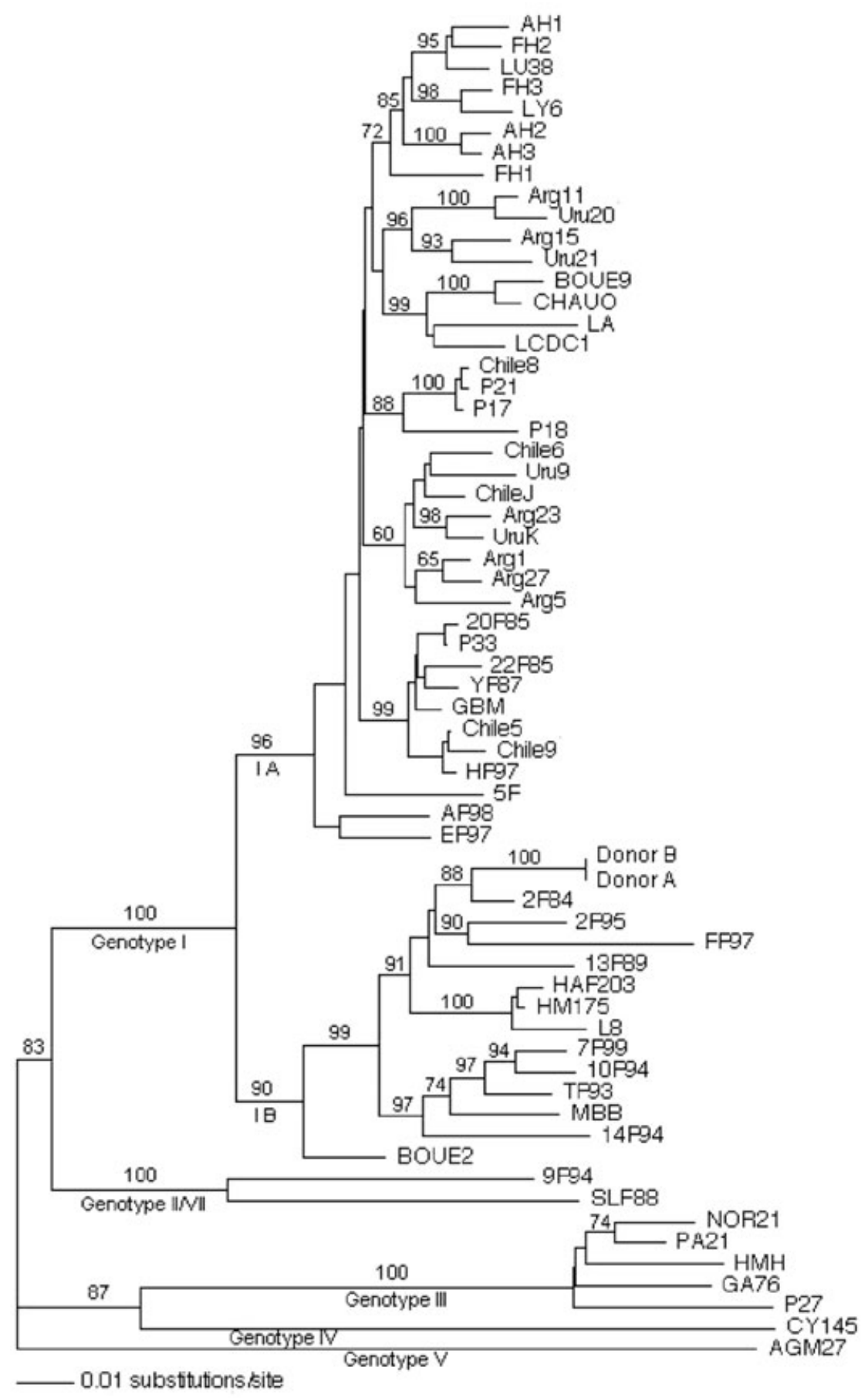

Fig. 1. Phylogenetic analysis of the two HAV strains isolated of the plasma unit (Donors A and B). Numbers at the branches indicate bootstrap percentage after 1000 replications of bootstrap sampling. The bar indicates genetic distance. in known regions of known high risk for hepatitis A, but also in certain areas where the risk has not been recognized. When blood is donated shortly after a stay in an HAV high-risk region, either testing donations by HAV NAT or a temporary deferral of donors (when common source outbreaks are recognized) is appropriate to prevent transfusiontransmitted infections.

Eva-Maria Zayc-Schmidt, MD e-mail: e.zayc-schmidt@bsdwest.de

Lutz Pichl, PhD German Red Cross Blood Transfusion Service West Central Laboratory Hagen, Germany

Thomas Laue, BSc Alke Heitmann, BSc artus $\mathrm{GmbH}$

Hamburg, Germany

Volkmar Schottstedt, MD

German Red Cross Blood Transfusion Service West

Central Laboratory

Hagen, Germany

\section{REFERENCES}

1. Gowland P, Fontana S, Niederhauser C, Mansouri Taleghani B. Molecular and serologic tracing of a transfusiontransmitted hepatitis A virus. Transfusion 2004;44:1555-61.

2. Blood Products Advisory Committee Meeting. FDA's current thinking on hepatitis A virus (HAV) NAT for blood and plasma [Internet]. Rockville (MD): Food and Drug Administration; 2002 Mar 14-15. Available from: http:// www.fda.gov/OHRMS/DOCKETS/ac/ 02/briefing/3839b1_03_issue.htm

3. Costa-Mattioli M, Cristina J, Romero H, et al. Molecular evolution of hepatitis A virus. a new classification based on the complete VP1 protein. J Virol 2002;76: 9516-25.

4. Centers for Disease Control and

not been identified. ${ }^{4}$ Four weeks after the donors departed, however, one of the hotels was identified as the source of more than 300 cases of hepatitis A among European tourists. ${ }^{5}$

This experience alerts us that there is a substantial risk for hepatitis A among nonvaccinated tourists not only Prevention (CDC). Hepatitis A outbreak associated with
green onions at a restaurant-Monaca, Pennsylvania, 2003. MMWR Morb Mortal Wkly Rep 2003;52:1155-7.

5. Frank C, Stark K. Cases of travel-associated hepatitis A in Germany: international alert. Eurosurveillance Weekly 2004;8:26/08/2004. 


\section{Lack of correlation between hepatitis B surface antigen and hepatitis B virus DNA levels in blood donors}

Kuhns and coworkers ${ }^{1}$ report a lack of correlation between hepatitis B surface antigen (HBsAg) and hepatitis B virus (HBV) DNA levels in chronic carriers of HBV. We would like to confirm this conclusion with data obtained in blood donors from Kumasi, Ghana, West Africa. In all cases, samples were stored at $-20^{\circ} \mathrm{C}$ or below and transported in dry ice.

The first set of donors was tested in 1999 to 2000 with an HBsAg enzyme immunoassay (EIA; Abbott/Murex, Dartford, UK) that has a sensitivity of $0.2 \mathrm{ng}$ per $\mathrm{mL}$. Seroreactive deferred donor samples were confirmed with an alternative EIA (Biokit, Valencia, Spain) and tested for alanine aminotransferase (ALT) level (upper normal level, $40 \mathrm{IU} / \mathrm{L}$ ). Forty donors from the same set were selected for having on two consecutive occasions, at least 1 month apart, an ALT level above $60 \mathrm{IU}$ per L (range, 60-865; median, 185) as evidence of liver disease and entry criteria in a randomized clinical trial for treatment with a local, plant-derived drug.

There were 32 men and 8 women, ranging in age between 17 and 54 years (median, 24 years). Viral load was quantified using an in-house real-time PCR (Q-PCR) as previously described. ${ }^{2}$ It ranged between 15 and $4.1 \times 10^{8}$ $\mathrm{IU}$ and $\mathrm{mL}$. Twenty-two samples had a viral load of greater than $1 \times 10^{4}$ and were HBeAg-positive, whereas the other 18 samples were below that level and were anti-HBepositive.
HBsAg was semiquantified in the following way. Plasma samples were serially diluted by a factor of 10 in saline, and each of the seven dilutions was tested with the HBsAg screening EIA. Reactivity was expressed as sample-to-cutoff ratio (S/CO). S/COs were then plotted against dilution on a bilogarithmic scale, and the two to four samples with a S/CO below maximum were used to derive a best-fit curve that intersected the base line of $\mathrm{S} /$ $\mathrm{CO}$ of 1 . This intersection was considered as extinction dilution and taken as reflecting the concentration of HBsAg.

As shown in Fig. 1A, no correlation was found between viral load that reflects the viral replication and HBsAg endpoint dilution that reflects the level of synthesis of surface protein. All but one sample gave a positive signal with the EIA when diluted 1:100,000 or higher. Seven of eight samples containing less than $100 \mathrm{IU}$ per mL HBV DNA (approximately 500 copies) gave a positive signal when diluted 1:1 mol per L. Conversely, the apparent level of circulating surface protein in samples containing more than $10^{7} \mathrm{IU}$ per $\mathrm{mL}$ was similar to samples with the lowest DNA copy number.

A second group of donors was first tested before donation in 2002 to 2003 with a rapid test (Determine HBsAg, Abbott, Delkenheim, Germany) with a $1 \mathrm{ng}$ per $\mathrm{mL}$ limit of detection. Negative donations were then tested by EIA (HBsAg Murex/Abbott) without dilution and found to be reactive. All samples were negative for the presence of anti-HBs. When tested by Q-PCR for the presence of HBV DNA, 53 samples were positive. In 45 cases, S/CO was between 1 and a maximum of 10 . In that zone, S/CO was
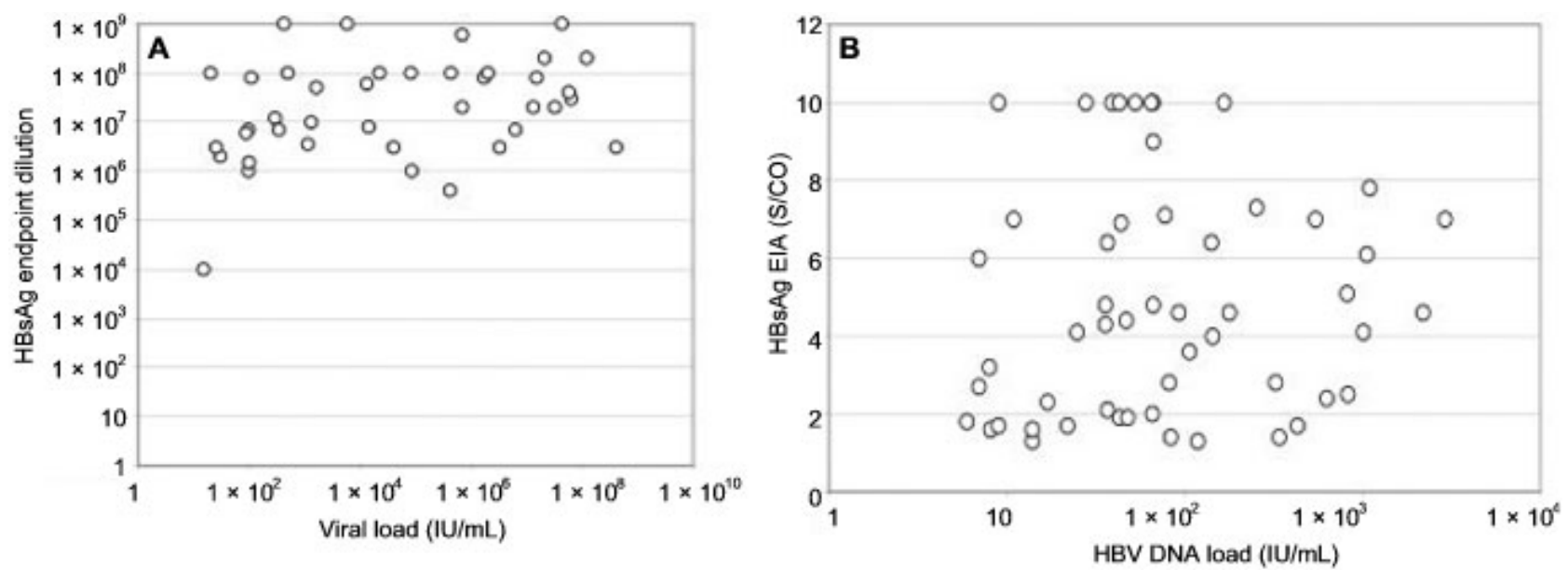

Fig. 1. (A) HBV DNA was quantified by real-time PCR as described in Allain et al. ${ }^{2}$ Results are expressed in IU per $\mathrm{mL}$. One IU per $\mathrm{mL}$ corresponds to approximately 5 copies per $\mathrm{mL}$. All donors had ALT levels of greater than $60 \mathrm{IU}$ per L, and samples were tested before any antiviral treatment was undertaken. (B) Blood donations did not react with a HBsAg rapid test (sensitivity, $1 \mathrm{ng} / \mathrm{mL}$ ) used before donation did react with an EIA (sensitivity, $0.2 \mathrm{ng} / \mathrm{mL}$ ). A majority of samples had a sample to cutoff ratio below maximum and a viral load below 100 IU per mL. 
expected to reflect HBsAg concentration. Figure 1B shows the absence of correlation between HBsAg S/CO and HBV DNA load. Nearly all samples contained less than 1000 IU per mL HBV DNA, and 33 (62\%) contained less than $100 \mathrm{IU}$ per $\mathrm{mL}$ or approximately 500 copies per $\mathrm{mL}$. Five samples (9.4\%) were anti-HBc-negative.

Both sets of data presented concur with the results of Kuhns and coworkers ${ }^{1}$ showing that, in chronic HBV infection, the apparent concentration of surface antigen in plasma does not correlate with the level of circulating viral DNA. This might reflect the considerable difference between the release of viral structural proteins and the formation of full virions released in the circulation. Nonencapsidated viral DNA tends to be rapidly destroyed whereas, in the absence of anti-HBs, surface antigen produced by either infected cells or integrated viral genome may remain in circulation for prolonged periods of time.

The gap in apparent HBsAg concentration between the first and second set of data is difficult to explain. Thirteen samples in the first set had a viral load below $1000 \mathrm{IU}$ per $\mathrm{mL}$, similar to what was found in the second set. Yet, $\mathrm{S} / \mathrm{CO}$ below the maximum absorbance level was found after dilution of more than $10^{4}$ in the first set and undiluted in the second, with the same EIA. Although the population of donors with liver disease tended to be older than those in set 2 , and those in the first set with viral load below $1 \times 10^{4} \mathrm{IU}$ per $\mathrm{mL}$ also tended to be older (median, 23 years vs. 28 years), neither difference was significant. It is possible that donors with liver disease have more integrated viral DNA producing HBsAg but no virions. The dual origin of HBsAg (viral replication and production from integrated DNA) might explain the presence of rare cases ( $3 \%$ in Kuhns et al. ${ }^{1}$ and $2 \%$ in Allain et al. ${ }^{2}$ ) of detectable HBsAg without detectable HBV DNA. In such cases, a very low production of potentially infectious virus cannot be excluded. Conversely, the presence of occult HBV infection (HBV DNA-positive, HBsAg-negative) might not be rare in some populations. ${ }^{3,4}$ As a result, blood safety might continue to benefit from sensitive detection methods of both HBsAg EIA and HBV DNA.

Jean-Pierre Allain, MD, PhD

Department of Haematology University of Cambridge

Francis Sarkodie, MSc Transfusion Medicine Unit Komfo Anokye Teaching Hospital Daniel Candotti, PhD National Blood Service Cambridge Blood Center

Cambridge, UK

Ohene Opare-Sem, MD Department of Medicine, Komfo Anokye Teaching Hospital Kumasi, Ghana

\section{REFERENCES}

1. Kuhns MC, Kleinman SH, McNamara AL, et al. Lack of correlation between HBsAg and HBV DNA levels in blood donors who test positive for HBsAg and anti-HBc: implications for future screening policy. Transfusion 2004;44:1332-9.

2. Allain JP, Candotti D, Soldan $\mathrm{K}$, et al. The risk of hepatitis B virus infection by transfusion in Kumasi. Ghana Blood 2003;101:2419-25.

3. Allain JP. Occult hepatitis B virus infection: implications in transfusion. Vox Sang 2004;86:83-91.

4. Owusu-Ofori S, Temple J, Sarkodie F, et al. Predonation screening of blood donors with rapid tests: implementation and efficacy of a novel approach to blood safety in resourcepoor settings. Transfusion 2005;45:133-40.

\section{Yield of hepatitis $\mathrm{C}$ virus nucleic acid testing among antibody-reactive or confirmed- positive samples}

In contrast to acute hepatitis B virus infections in adults, of which only 1 to 3 percent become chronic, acute hepatitis $\mathrm{C}$ virus (HCV) infections progress to chronicity in a high proportion of cases, with reported rates of persistent viremia of up to 85 percent. ${ }^{1,2}$ Spontaneous HCV clearance has been correlated with age at infection, race-ethnicity, HLA type, coinfection by other viruses, and immunosuppression. ${ }^{3-5}$ Rates of HCV viremia detected by nucleic acid testing (NAT) have ranged from 74 to 86 percent in large seropositive populations, such as anti-HCV-reactive donors ${ }^{6-10}$ HCV NAT rates, however, may become lower with increased use of NAT and the introduction of more sensitive third-generation antibody assays.

In a recent article on NAT yield in German blood donors, Roth and coworkers ${ }^{11}$ reported HCV viremia rates for 462 anti-HCV-positive donations confirmed by a second-generation semiautomated HCV antibody assay (Matrix, Abbott Laboratories, Delkenheim, Germany; before summer 2001) and antibody-reactive results confirmed by an HCV line immunoassay (Inno-Lia HCV antibody III update, Innogenetics, Gent, Belgium; after summer 2001). These seropositive samples had been tested by HCV NAT in pools containing up to 96 donor samples, and if RNA-negative, by single-sample NAT. Of 268 donor samples from the German Red Cross Institute Frankfurt, 187 (69.8\%) tested RNA-positive, whereas only 84 (43.3\%) of 194 samples from the Bavarian Red Cross tested positive by NAT. The surprisingly low rate of viremia observed in the HCV seropositive donors from the Bavarian Red Cross (relative to other donor populations in Germany and elsewhere) could not be explained by known correlates of clearance, which led to this investigation. 
To confirm the RNA and antibody status of blood donor samples that had been classified as NAT-negative and HCV-seropositive in the previously published report, 110 of the original Bavarian donor samples and 5 of the original donor samples from Frankfurt were reanalyzed by two independent laboratories (Blood Systems Research Institute, San Francisco, CA, in collaboration with Chiron Corp., Emeryville, CA; and the German Red Cross Institute Frankfurt). The working plan and results from both laboratories are summarized in Fig. 1. All samples tested negative for the presence of HCV RNA (TMA Procleix Ultrio [Chiron Corp.] in San Francisco and in-house single-sample polymerase chain reaction [PCR] in Frankfurt), confirming the sensitivity of the original NAT screening system. Antibodypositive samples were confirmed by a third-generation HCV recombinant immunoblot assay (RIBA) (US) and by Inno-Lia HCV antibody III update (Germany). Whereas all five original samples from Frankfurt were confirmed HCV antibody-positive in both laboratories, only 9 of 51 Bavarian samples could be confirmed for the presence of HCV antibody with RIBA and 16 of 43 samples could be confirmed with Inno-Lia HCV antibody III update. Based on these confirmed HCV antibody results, the recalculated rates of viremia by minipool and single-sample PCR among the HCV antibody confirmed-positive samples were 187 of $268(69.8 \%)$ and 84 of $109(77 \%)$ for the Frankfurt and Bavarian Red Cross Centers, respectively. Therefore, there was no significant difference between the rates of viremia in these donor populations (chi-square test; $p=0.19$ ), in accordance with other results in the literature.

Thus, the explanation for the low rate of reported viremia among the Bavarian donors was the inclusion of false-positive donor samples in the denominator of confirmed-positive donors, rather than the sensitivity of the NAT screening assay or unique demographic or epidemiologic factors. One explanation for these results could be the use of the less specific Matrix assay instead of RIBA or Inno-Lia HCV antibody III update in the initial study for confirmation of HCV antibody-reactive samples. In each institute (Bavarian Red Cross and German Red Cross Institute Frankfurt), 50 Inno-Lia HCV antibody III updatepositive donations were additionally analyzed by NAT between 2001 and 2004. The Bavarian samples and the Frankfurt samples were 62 and 70 percent NAT positive, respectively. The recent data from both institutes is there- fore in accordance with the literature and our retest results and indicate no significant difference between rates of HCV viremia among seropositive donors from either region. It is not possible, retrospectively, to determine the exact source of technical problems with the application of the second-generation Matrix HCV test at the Bavarian Red Cross before 2001.

Michael Schmidt, MD Institute of Transfusion Medicine and Immunohematology German Red Cross Johann Wolfgang Goethe University Frankfurt, Germany Marijke Weber, PhD Institute Wiesentheid of the Bavarian Red Cross Wiesentheid, Germany

Michael P. Busch, MD, PhD

Leslie H. Tobler, DrPH Blood Systems Research Institute San Francisco, $C A$

Bruce H. Phelps, PhD Chiron Corporation Emeryville, $C A$

Erhard Seifried, MD

Institute of Transfusion Medicine and Immunohematology German Red Cross Johann Wolfgang Goethe University Frankfurt, Germany e-mail:eseifried@bsdhessen.de 
W. Kurt Roth, MD

Institute of Transfusion Medicine and Immunohematology

German Red Cross

Johann Wolfgang Goethe University

Frankfurt, Germany

e-mail:wroth@bsdhessen.de

\section{REFERENCES}

1. Farci P, Purcell RH. Clinical significance of hepatitis $C$ virus genotypes and quasispecies. Semin Liver Dis 2000;20:10326.

2. Villano SA, Vlahov D, Nelson KE, et al. Persistence of viremia and the importance of long-term follow-up after acute hepatitis C infection. Hepatology 1999;29:908-14.

3. Sugimoto K, Stadanlick J, Ikeda F, et al. Influence of ethnicity in the outcome of hepatitis $\mathrm{C}$ virus infection and cellular immune response. Hepatology 2003;37:590-9.

4. Thio CL, Thomas DL, Goedert JJ, et al. Racial differences in HLA class II associations with hepatitis C virus outcomes. J Infect Dis 2001;184:16-21.

5. Thio CL, Gao X, Goedert JJ, et al. HLA-Cw*04 and hepatitis C virus persistence. J Virol 2002;76:4792-7.

6. Alvarez-Munoz MT, Vences-Aviles MA, Damacio L, et al. Hepatitis C virus RNA (HCV-RNA) in blood donors and family members seropositive for anti-HCV antibodies. Arch Med Res 2001;32:442-5.

7. Conry-Cantilena C, VanRaden M, Gibble J, et al. Routes of infection, viremia, and liver disease in blood donors found to have hepatitis C virus infection. N Engl J Med 1996;334: 1691-6.

8. Davoren A, Dillon AD, Power JP, et al. Outcome of an optional HCV screening program for blood transfusion recipients in Ireland. Transfusion 2002;42:1501-6.

9. Elghouzzi MH, Bouchardeau F, Pillonel J, et al. Hepatitis C virus: routes of infection and genotypes in a cohort of antiHCV-positive French blood donors. Vox Sang 2000;79:13844.

10. Fan WM, Zhu WF, Yin LM, et al. Prospective study in 142 cases of hepatitis C virus infection. World J Gastroenterol 2004;10:2867-9.

11. Roth WK, Weber M, Buhr S, et al. Yield of HCV and HIV-1 NAT after screening of 3.6 million blood donations in central Europe. Transfusion 2002;42:862-8.

\section{Re: Toward an understanding of transfusion- related acute lung injury: statement of a consensus panel}

The recently published consensus statement on understanding transfusion-related acute lung injury (TRALI) ${ }^{1}$ contains several errors pertaining to the work of our group (authors' reference 21). ${ }^{2}$ Suspecting that the errors might reflect an incorrect bibliographical citation, we searched computerized databases, but cannot find an explanation. Virtually all of the citations to our work in this consensus statement are incorrect, as follows:

- "Rat lungs were ventilated, perfused ...." We did not use rat but rabbit lungs.

- "... and subsequently monoclonal anti-HNA$2 \mathrm{a} . .$. was added to the perfusate ...." We did not use monoclonal, but polyclonal, alloantibodies from a blood donor, implicated in TRALI.

- (Same as above) The specificity of the antibody, added to the perfusate, was anti-HNA-3a or in former terminology anti-5b, not anti-HNA-2a.

- "The response was blunted when less than 30 percent HNA-2a-positive neutrophils were used." We did not find such a threshold of 30 percent and did not mention it.

- "The onset of these events was accelerated by the addition of the neutrophil activator formyl-methionyl-leucyl-phenylalanine." We did not use this activator.

- "Lung histology showed pulmonary edema and neutrophil accumulation." We did not perform histology; we just evaluated cell counts and microscopic smears.

Erroneous citations in this widely read consensus statement will, we are concerned, lead to misunderstandings with regard to our past, present, and future research in this field..$^{3-8}$ They should be rectified.

Jürgen Neppert, MD e-mail: juergen.neppert@web.de Esther v. Witzleben-Schürholz, MD Institute of Transfusion Medicine University Clinics Schleswig-Holstein Kiel, Germany

\section{REFERENCES}

1. Kleinman S, Caulfield T, Chan P, et al. Toward an understanding of transfusion-related acute lung injury: statement of a consensus panel. Transfusion 2004;44:1774-89.

2. Seeger W, Schneider U, Kreusler B, et al. Reproduction of transfusion-related acute lung injury in an ex-vivo lung model. Blood 1990;76:1438-44.

3. v. Witzleben E, Neppert J, Seeger W, et al. Untersuchungen eines humanen leukagglutinierenden 5b-Antikörpers am Modell der isolierten Kaninchenlunge im Hinblick auf dessen lungenschädigenden Effekt. Infusionstherapie 1990;17:333-4.

4. Grimminger F, Kreusler B, Schneider U, et al. Human leukagglutinating antibody evokes cooperative leukotriene synthesis in pulmonary microvasculature: model of transfusion-related acute lung injury. Circ Res 1991;68: 503-12. 
5. Leger R, Palm S, Wulf H, Vosberg A, Neppert J. Transfusionrelated lung injury with leukopenic reaction caused by fresh frozen plasma containing anti-NB1. Anesthesiology 1999; 91:1529-32.

6. v. Witzleben-Schürholz E, Neppert J, Schmidt L, Rohr A, Leger R. Another case of transfusion-related lung injury due to anti-HNA-3a (-5b). Infus Ther Transfus Med 2000;27:20810.

7. Engelfriet CP, Reesink HW, Brand A, et al. Transfusionrelated acute lung injury (TRALI). Vox Sang 2001;81:269-83.

8. Flesch BK, Neppert J. Transfusion-related acute lung injury caused by human leucocyte antigen class II antibody. Br J Haematol 2002;116:673-6.

The above letter was sent to Kleinman et al.: Drs Davenport and Kleinman offered the following reply.

We thank Neppert and v. Witzelben-Schürholz for their comments about our incorrect citation of their work and extend our sincere apologies to them and their colleagues. The data in our report attributed to Seeger and colleagues (our reference 21) should have been attributed to Bux. Bux presented these data on their ex vivo rat lung model at the consensus conference and have published these data in abstract form. ${ }^{1}$

Although the data were not presented at this conference, Neppert and colleagues previously published important pioneering work on an ex vivo model of transfusion-related acute lung injury (TRALI). ${ }^{2}$ As pointed out in their letter, this model used isolated rabbit lungs that were perfused with human neutrophils, plasma containing anti-5b, and fresh rabbit plasma as a complement source. Appropriate control experiments were also conducted.

We would like to emphasize that apart from this incorrect citation, the consensus statement as published in TRANSFUSION accurately reflects the proceedings of the conference and the consensus of the full panel. ${ }^{3}$

Robertson Davenport, MD Steven Kleinman, MD On behalf of the TRALI Conference Consensus Panel e-mail: skleinman@shaw.ca

\section{REFERENCES}

1. Bux J, Hardt O, Kohstall M, Sibelius U, Weissmann N. Reproduction of granulocyte antibody-mediated TRALI in an ex-vivo rat lung model. Blood 2003;102(Suppl):94a.

2. Seeger W, Schneider U, Kreusler B, et al. Reproduction of transfusion-related acute lung injury in an ex-vivo lung model. Blood 1990;76:1438-44.

3. Kleinman S, Caulfield T, Chan P, et al. Toward an understanding of transfusion-related acute lung injury: statement of a consensus panel. Transfusion 2004;44:1774-89.

\section{Naturally occurring anti-Jk}

We report a case of "naturally occurring" anti-Jk $\mathrm{k}^{\mathrm{a}}$ in a 7month-old boy with orchitis, epididymitis, and an Escherichia coli urinary tract infection.

The boy was born via cesarean section after 38 weeks of his mother's first and uneventful pregnancy. She had no history of transfusion. Physical examination was unremarkable, except for a tender mass in the left scrotum, which was consistent with orchitis or epididymitis by color Doppler examination. The complete blood cell count was normal. Culture of a midstream urine sample grew E. coli, more than $10^{5}$ colony-forming units per $\mathrm{mm}^{3}$. His red blood cells (RBCs) typed as group $\mathrm{O}, \mathrm{D}+$. An antibody detection test was positive and anti-Jk ${ }^{\mathrm{a}}$ was identified by gel test using a low-ionic-strength saline (LISS)-Coombs card (DiaMed AG, Cressier, Morat, Switzerland). An antibody detect test was negative when repeated using a NaCl-enzyme card (DiaMed AG, Cressier). Anti-Jk ${ }^{\mathrm{a}}$ activity was not reduced by dithiothreitol treatment, suggesting that the antibody was mostly immunoglobulin G (IgG). We did not perform a monocyte monolayer or other in vitro assay to evaluate the potential clinical significance of the antibody. The patient's and his mother's RBCs typed as $\mathrm{Jk}(\mathrm{a}-\mathrm{b}+)$. Both had negative results for direct antiglobulin tests and anti-nuclear antibody tests. The mother's antibody detection test was negative.

These serologic findings were unchanged on four subsequent serum samples collected during an 8-day hospitalization. An antibody detection test was negative when repeated 6 months after discharge.

We are aware of only one other case report of naturally occurring anti-Jk ${ }^{\mathrm{a}}{ }^{1}$ In that report, anti-Jk ${ }^{\mathrm{a}}$ was detected by strong serologic reactivity in a solid-phase RBC adherence (SPRCA) assay, but not by indirect antiglobulin test tube method in LISS or polyethylene glycol or with papain- or ficin-treated RBCs. In contrast, anti-Jk ${ }^{\mathrm{a}}$ in our patient had strong reactivity in the gel test, which we consider to be less sensitive than SPRCA. We are able to exclude primary alloimmunization because of maternal-fetal hemorrhage, because the patient's and his mother's RBC phenotypes were Jk(a-). Primary alloimmunization via maternal-fetal hemorrhage could not be excluded in the first report of naturally occurring anti-Jk $\mathrm{k}^{\mathrm{a}}$, because the mother's RBCs were $\mathrm{Jk}(\mathrm{a}+){ }^{1}$

Perhaps the most interesting finding in our study is the $E$. coli genitourinary infection. Several studies have described an association between blood group antigens and microbial infections, ${ }^{2-5}$ although there appears to be only one report associating infection and Kidd blood group antigens. ${ }^{5}$ That report described transient autoanti-Jk ${ }^{\mathrm{b}}$ in a patient with a proteus urinary tract infection.

Typically, naturally occurring antibodies are immunoglobulin $\mathrm{M}$ and, uncommonly, IgG as in our patient. 
The basis for this phenomenon is not known. In the absence of information concerning the clinical significance of naturally occurring anti-Jk ${ }^{\mathrm{a}}$, in general, and for our patient's anti-Jk ${ }^{\mathrm{a}}$, specifically, we have recommended that $\mathrm{Jk}(\mathrm{a}-)$ RBCs be selected, if our patient requires a future transfusion.

Although anti-Jk ${ }^{\mathrm{a}}$ is detected rarely in the absence of exposure allogeneic Jk(a+) RBCs, we suggest that anti-Jk ${ }^{\mathrm{a}}$ be added to future listings of blood group antibodies that may be "naturally occurring."

Hyung Hoi Kim, MD, PhD e-mail:hhkim@pusan.ac.kr

Tae Sung Park, MD Department of Laboratory Medicine

Wan Lee, MD

Sang Don Lee, MD, PhD

Department of Urology

Pusan National University

College of Medicine

Busan, Korea

Hyun Ok Kim, MD, PhD

Department of Laboratory Medicine

Yonsei University

College of Medicine

Seoul, Korea

\section{REFERENCES}

1. Rumsey DH, Nance SJ, Rubino M, Sandler SG. Naturallyoccurring anti-Jk ${ }^{\mathrm{a}}$ in infant twins. Immunohematology 1999;15:159-62.

2. Savalonis JM, Kalish RI, Cummings EA, Ryan RW, Aloisi R. Kell blood group activity of gram-negative bacteria. Transfusion 1988;28:229-32.

3. Kanel GC, Davis I, Bowman JE. "Naturally-occurring" antiK1: possible association with mycobacterium infection. Transfusion 1978;18:472-3.

4. Judd WJ, Walter WJ, Steiner EA. Clinical and laboratory findings on two patients with naturally occurring anti-Kell agglutinins. Transfusion 1981;21:184-8.

5. McGinniss MH, Leiberman R, Holland PV. The $\mathrm{Jk}^{\mathrm{b}}$ red cell antigen and gram-negative organisms. Transfusion 1979; 19:663.

\title{
SUBMISSION OF LETTERS
}

Instructions for submission of letters can be found in the Detailed Instructions for Authors published on pages 128 to 133 of the January issue. Submit letters to:

\author{
S. Gerald Sandler, MD \\ Department of Laboratory Medicine/M-1306 \\ Georgetown University Hospital \\ 3800 Reservoir Road, NW, Washington, DC 20007 \\ fax (202) 444-2440 \\ e-mail: sandlerg@gunet.georgetown.edu
}

EDITOR'S NOTE: To permit timely publication of correspondence, the references have not been verified as they are for articles appearing in TRANSFUSION, and, therefore, the accuracy of references cited in Letters to the Editor is the sole responsibility of the authors. Payment is not required for submission of Letters to the Editor. 